\title{
Pelatihan Deteksi Formalin dan Rhodamin B dalam Makanan bagi Guru dan Wali Murid Taman Kanak-Kanak Bintara Jaya Bekasi
}

\author{
Sofia Fatmawati ${ }^{*}$, Hurip Budi Riyanti ${ }^{2}$, Kori Yati ${ }^{3}$ \\ Fakultas Farmasi dan Sains, Universitas Muhammadiyah Prof Dr Hamka ${ }^{1,2,3}$ \\ sofia.fatmawati@uhamka.ac.id*, huripbudi@gmail.com, koriyati@uhamka.ac.id
}

\begin{abstract}
People in general, consumes food which is homecooked or buying finished products every day. Many types of prepared fast foods used food additives such as preservatives, flavorings agents, sweeteners etc. Additives which being used must be safe for consumption in a certain limit. The community service was held to the teachers and parents from Bintara Jaya Bekasi Kindergarten in order to quickly detect additional ingredients offformaldehyde and rhodamine in food and using a test kit. The target is to increase the knowledge and skills of the teachers and parents from Bintara Jaya Bekasi Kindergarten students to detect and test foods containing formaldehyde and rhodamine $B$ because the commons does not yet understand between safe and prohibited food additives. This workshop can improve the quality of health in the school and family environment. The training was done by lecturing method, practicing rapid detection and using a test kit and followed by discussion. The results of the community service showed an increase in the knowledge and skills of the teachers and parents from Bintara Jaya Bekasi Kindergarten in detecting foods containing formaldehyde and rhodamine $B$.
\end{abstract}

Keywords: Formaldehyd; Rhodamin; Detection; Food; Additives.

\begin{abstract}
Abstrak
Masyarakat pada umumnya, setiap hari mengkonsumsi makanan yang dimasak sendiri maupun membeli produk jadi. Jenis jenis makanan siap saji yang beredar, banyak menggunakan bahan tambahan pangan seperti pengawet, penyedap, pemanis dll. Bahan tambahan yang digunakan tentunya harus aman untuk dikonsumsi dengan batas tertentu. Pengabdian dilaksanakan bertujuan agar para guru dan wali murid Taman Kanak-Kanak (TK) Bintara Jaya Bekasi mampu mendeteksi bahan tambahan yang dilarang yaitu formalin dan rhodamin dalam makanan secara cepat dan menggunakan test kit. Target yang dicapai adalah peningkatan pemahaman dan ketrampilan para guru dan wali murid TK Bintara Jaya Bekasi untuk mendeteksi dan menguji makanan yang mengandung formalin dan rhodamin B karena masyarakat umumnya belum paham bahan tambahan makanan yang aman atau berbahaya. Pelatihan ini dapat meningkatkan derajat kualitas kesehatan di lingkungan sekolah dan keluarga. Metode pelaksanaan pelatihan dilakukan dengan metode ceramah, praktek deteksi cepat dan menggunakan test kit dilanjutkan dengan tanya jawab dan diskusi. Hasil kegiatan menunjukkan peningkatan pengetahuan dan ketrampilan para guru dan wali murid TK Bintara Jaya Bekasi dalam mendeteksi makanan yang mengandung formalin dan rhodamin B.
\end{abstract}

Kata kunci: Formalin; Rhodamin; Deteksi; Bahan tambahan pangan. 


\section{A. PENDAHULUAN}

Kegiatan Pengabdian Masyarakat merupakan aplikasi dari terwujudnya Tridharma Perguruan Tinggi dalam mengupayakan keilmuan dan ketrampilan akademis ditengah masyarakat. Pelaksanaan kegiatan pengabdian dengan tema "Pelatihan Deteksi Formalin dan Rhodamin B dalam Makanan bagi Guru dan Wali Murid TK Bintara Jaya Bekasi“ merupakan bentuk kepedulian dosen Farmasi UHAMKA yaitu untuk peningkatan pemahamam para guru dan wali murid TK Bintara Jaya Bekasi dalam mendeteksi makanan yang aman. Mereka setiap hari mengkonsumsi makanan, baik memasak sendiri maupun yang membeli produk jadi. Jenis jenis makanan siap saji yang beredar banyak menggunakan bahan tambahan pangan seperti pengawet, penyedap, pemanis, pewarna dan sebagainya.

Pengawet (preservative) adalah bahan tambahan pangan untuk mencegah atau menghambat fermentasi, pengasaman, penguraian, dan perusakan lainnya terhadap pangan yang disebabkan oleh mikroorganisme. Jenis pengawet yang diijinkan antara lain: Asam sorbat dan garamnya; Asam benzoat dan garamnya; Etil para-hidroksibenzoat; Metil parahidroksibenzoat; Sulfit; Nisin; Nitrit; Nitrat; Asam propionat dan garamnya; dan Lisozim hidroklorida (Perka Badan POM No. 36 tahun 2013).

Pewarna (Colour) adalah bahan tambahan pangan berupa Pewarna alami dan Pewarna sintetis, yang ketika ditambahkan atau diaplikasikan pada pangan mampu memberi atau memperbaiki warna. Pewarna dibagi menjadi 2 yaitu Pewarna alami dan pewarna sintetik. Contoh pewarna alami adalah kurkumin dan klorofil. Sedangkan contoh pewarna sintetik adalah tartrazine dan eritrosin (Perka Badan POM No. 37 tahun 2013).
Bahan-bahan tambahan tersebut tentunya aman untuk dikonsumsi tetapi dengan batas batas tertentu, selain itu terdapat bahan tambahan yang dilarang digunakan seperti rhodamin $\mathrm{B}$, formalin dsb (BPOM, 2013). Pengawasan bahan tambahan berbahaya yang disalahgunakan dalam makanan tertuang dalam peraturan bersama menteri dalam negeri Indonesia dan Kepala Badan POM No 43 tahun 2013 dan 2 tahun 2013 antara lain Asam Borat; Boraks; Formalin (larutan formaldehid); Paraformaldehid (Serbuk dan Tablet Paraformaldehid); Pewarna Merah Rhodamin B; Pewarna Merah Amaranth; Pewarna Kuning metanil (Methanil Yellow); dan Pewarna Kuning Auramin.

Formalin (larutan formaldehid), paparan formaldehid melalui saluran pencernaan dapat mengakibatkan luka korosif terhadap selaput lendir saluran pencernaan disertai mual, muntah, rasa perih yang hebat dan perforasi lambung. Efek sistemik dapat berupa depresi susunan syaraf pusat, koma, kejang, albuminaria, terdapatnya sel darah merah di urine (hematuria) dan asidosis metabolik. Dosis fatal formalin melalui saluran pencernaan pernah dilaporkan sebesar $30 \mathrm{ml}$. Formaldehid dapat mematikan sisi aktif dari protein- protein vital dalam tubuh, maka molekul-molekul itu akan kehilangan fungsi dalam metabolisme. Akibatnya fungsi sel akan terhenti. Pada dasarnya, formaldehid dalam jaringan tubuh sebagian besar akan dimetabolisir kurang dari 2 menit oleh enzim formaldehid dehidrogenase menjadi asam format yang kemudian diekskresikan tubuh melalui urin dan sebagian dirubah menjadi $\mathrm{CO}_{2}$ yang dibuang melalui nafas. Fraksi formaldehid yang tidak mengalami metabolisme akan terikat secara stabil dengan makromolekul seluler protein DNA yang dapat berupa ikatan silang (crosslinked). Ikatan silang formaldehid dengan 
DNA dan protein ini diduga bertanggungjawab atas terjadinya kekacauan informasi genetik dan konsekuensi lebih lanjut seperti terjadi mutasi genetik dan sel kanker. Bila gen-gen rusak itu diwariskan, maka akan terlahir generasi dengan cacat gen. Dalam pada itu, International Agency Research on Cancer (IARC) mengklasifikasikannya sebagai karsinogenik golongan 1 (cukup bukti sebagai karsinogen pada manusia), khususnya pada saluran pernafasan (IARC, 2006).

Rhodamin B merupakan pewarna tekstil yang bisa menumpuk di jaringan lemak sehingga lama-kelamaan jumlahnya akan terus bertambah. Rhodamin B diserap lebih banyak pada saluran pencernaan dan menunjukkan ikatan protein yang kuat. Kerusakan pada hati tikus terjadi akibat makanan yang mengandung rhodamin B dalam konsentrasi tinggi. Paparan rhodamin B dalam waktu yang lama dapat menyebabkan gangguan fungsi hati dan kanker hati (Safitri, 2015). Penggunaan Bahan Tambahan Pangan seperti pemanis, pengawet dan pewarna diatur dalam Peraturan Kepala Badan POM dengan ambang batas tertentu sesuai jenis makanan (BPOM, 2012).

Mitra merupakan TK IT Al Iman Bintara Jaya mempunyai 8 kelas. Setiap kelas berisi kira kira 18-20 anak. Kegiatan sekolah dimulai pukul 07.00 s.d 12.00 wib. Lokasi terletak di daerah Bintara, Bekasi Barat. Jumlah guru pengajar sebanyak 30 orang, terdiri dari Kepala Sekolah dan guru pengajar. Mereka setiap hari mengkonsumsi makanan, baik yang bekal dari rumah maupun yang beli di kantin. Jenis jenis makanan siap saji yang beredar banyak yang menggunakan bahan tambahan pangan seperti pengawet, penyedap, pemanis dsb. Bahan tambahan tersebut tentunya ada yang aman untuk dimakan tetapi dengan batas batas tertentu, selain itu ada bahan yang dilarang digunakan karena tidak aman seperti rhodamin $\mathrm{B}$, formalin dan sebagainya.

Kebutuhan mitra tentang pengetahuan penggunaan bahan tambahan yang aman, karena sering adanya issue di media sosial, bahwa penggunaan bahan tambahan pangan umumnya tidak aman. Mitra perlu pemberian materi mengenai pengelompokan bahan tambahan makanan baik yang aman maupun berbahaya. Ketidaktahuan mitra mengenai cara pemeriksaan bahan tambahan berbahaya dalam makanan seperti formalin dan rhodamin. Tujuannya agar mitra bisa memilih dan menggunakan ataupun memeriksa bahan tambahan pangan yang aman digunakan, sehingga bisa menyediakan pangan yang aman bagi konsumennya, ataupun wali murid bisa menyeiakan pangan yang aman bagi putra putrinya.

\section{B. PELAKSAAAN DAN METODE}

Metode pelaksanaan kegiatan pengabdian kepada masyarakat ini yaitu dalam bentuk ceramah, praktek deteksi dan diskusi. Sasaran yang dipilih adalah guru dan wali murid TK Bintara Jaya Bekasi. Tempat yang dipilih adalah ruangan kelas TK Bintara Jaya Bekasi. Metode Ceramah digunakan untuk menyampaikan materi secara rinci tentang bahan pangan yang aman mupun berbahaya. Metode Praktik digunakan untuk mempraktikkan keterampilan deteksi cepat seperti pengamatan bentuk apakah lebih kenyal atau mudah hancur, warna yang sangat terang dan bau khas atau menyengat. Deteksi juga dilakukan menggunakan test kit yang telah disiapkan. Sampel makanan yang digunakan untuk uji formalin adalah tahu putih mentah, tahu kuning mentah, tahu goreng, mie basah putih dan mie basah kuning. Sampel untuk uji rhodamin B adalah krupuk mentah dan matang yang berwarna kuning serta merah. 


\section{Uji Formalin}

Uji formalin menggunakan prinsip pembentukan senyawa kompleks berwarna merah ungu dari reaksi antara formaldehid dengan 4 - amino -3 hidrazino -5 mercapto -1,2,4-triazole. Metodenya adalah dengan cara merendam kurang lebih 1-5 gram sampel dengan air, air rendaman kurang lebih $1 \mathrm{ml}$ dimasukkan ke dalam tabung reaksi. Ditambahkan $3-5$ tetes pereaksi I tetes demi tetes ke dalam tabung reaksi. Kemudian ditambahkan pereaksi II kurang lebih $1 \mathrm{mg}$ (menggunakan stick yang tersedia). Tabung reaksi dikocok dan diamati warna yang terbentuk. Sampel positif mengandung formalin jika terbentuk warna ungu. Hasil dibandingkan dengan kontrol positif formalin.

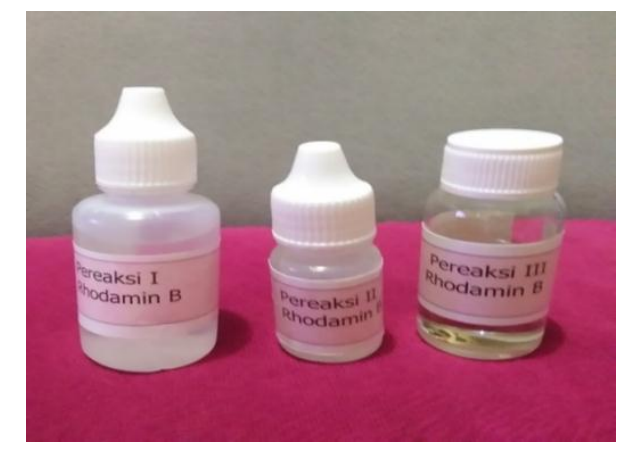

Gambar 1. Test Kit Pendeteksi Rhodamin B

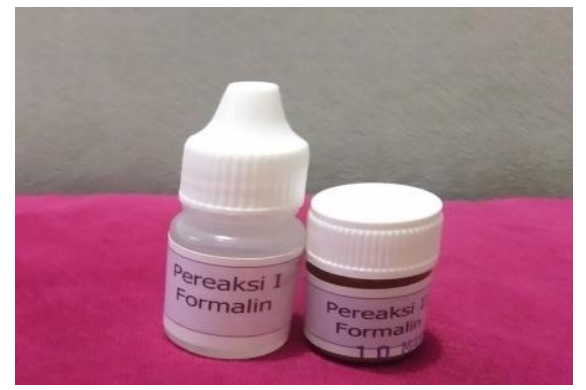

Gambar 2. Test Kit Pendeteksi Formalin

\section{Uji Rhodamin B}

Uji rhodamin B menggunakan prinsip Pembentukan senyawa kompleks berwarna ungu lembayung dari rhodamin $\mathrm{B}$ dengan garam antimon yang larut dalam pelarut organik. Metodenya adalah meendam kurang lebih 1 - 5 gram sampel dengan air, air rendaman kurang lebih $1 \mathrm{ml}$ dimasukkan ke dalam tabung reaksi. Pereaksi I sebanyak 10 tetes ditambahkan ke dalam tabung reaksi. Ditambahkan 5 tetes pereaksi II kemudian 10 tetes pereaksi III. Tabung reaksi dikocok dengan hati - hati. Jika berbentuk warna ungu (violet) pada lapisan atas maka sampel mengandung rhodamin B. Hasil dibandingkan dengan kontrol positif rhodamin B.

Diskusi setelah praktek digunakan untuk mengakomodasi pertanyaan atau masukan tentang materi yang telah disampaikan serta evaluasi pemahaman peserta mengenai materi pelatihan.

\section{C.HASIL DAN PEMBAHASAN}

Pangan adalah segala sesuatu yang berasal dari sumber hayati produk pertanian, perkebunan, kehutanan, perikanan, peternakan, perairan, dan air, baik yang diolah maupun tidak diolah yang diperuntukkan sebagai makanan atau minuman bagi konsumsi manusia, termasuk bahan tambahan pangan, bahan baku pangan, dan bahan lainnya yang digunakan dalam proses penyiapan, pengolahan, dan/atau pembuatan makanan atau minuman (BPOM, 2014).

$\begin{array}{lrr}\text { Bahan Tambahan Pangan } & \text { (BTP) } \\ \text { menurut PERMENKES RI } & \text { No. }\end{array}$
1168/MENKES/PER/X/1999 adalah bahan yang biasanya tidak digunakan sebagai makanan dan bukan merupakan ingredient khas makanan mempunyai atau tidak mempunyai nilai gizi; dengan sengaja ditambahkan ke dalam makanan untuk maksud teknologi (termasuk organoleptik) pada pembuatan, pengolahan, penyediaan, perlakuan, pewadahan, pembungkusan, penyimpanan atau pengangkutan makanan untuk menghasilkan atau diharapkan menghasilkan (langsung 
atau tidak langsung) suatu komponan yang mempengaruhi sifat khas makanan.

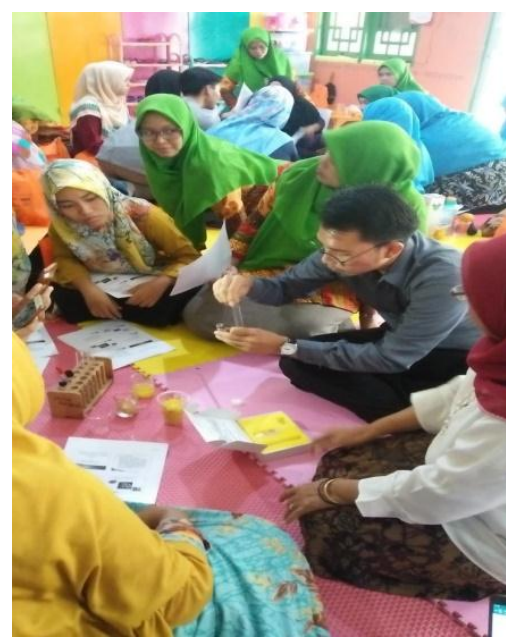

Gambar 3. Praktek Deteksi Formalin pada Sampel Mie Basah

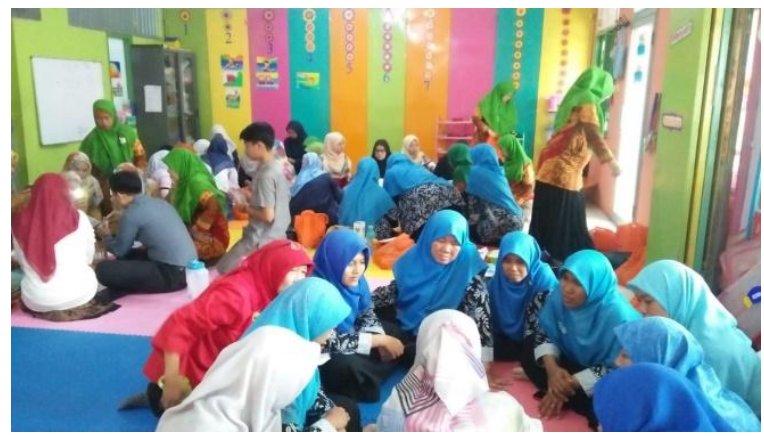

Gambar 4. Praktek Deteksi Formalin dan Rhodamin B secara Berkelompok

Pada pelatihan ini diikuti oleh guru dan wali murid TK Bintara Jaya Bekasi total sebanyak 42 orang dengan latar belakang masyarakat yang masih awam mengenai bahan tambahan pangan. Pelatihan diawali dengan penjelasan materi mengenai edukasi tentang bahan pangan yang aman maupun berbahaya diteruskan dengan tanya jawab singkat. Peserta dikenalkan mengenai jenis bahan pangan baik dalam bentuk mentah maupun produk jadi terdiri dari bahan baku dan bahan tambahan. Bahan tambahan pangan bisa berupa pengawet, pemanis, pewarna, antioksidant, perisa, dll. Beberapa bahan tambahan pangan ada yang berasal dari organik dan sintetik, dengan sisi kemanannya masing-masing.

Tabel 1. Hasil Analisa Formalin dan Rhodamin dalam Sampel Makanan

\begin{tabular}{llcc}
\hline \multirow{2}{*}{ No } & Sampel & \multicolumn{2}{c}{ Uji } \\
\cline { 2 - 4 } & & Formalin & Rhodamin B \\
\hline 1 & Tahu Putih & $(-)$ & N/A \\
2 & Tahu Kuning & $(+)$ & N/A \\
3 & Tahu Goreng & $(+)$ & N/A \\
4 & Mie basah putih & $(-)$ & N/A \\
5 & $\begin{array}{l}\text { Mie basah } \\
\text { kuning }\end{array}$ & $(+)$ & N/A \\
6 & $\begin{array}{l}\text { Krupuk mentah } \\
\text { kuning }\end{array}$ & N/A & $(-)$ \\
7 & $\begin{array}{l}\text { Krupuk mentah } \\
\text { kriting merah }\end{array}$ & N/A & $(+)$ \\
8 & $\begin{array}{l}\text { Krupuk matang } \\
\text { merah }\end{array}$ & N/A & $(+)$ \\
\hline
\end{tabular}

Formalin sebagai pengawet yang tidak diijinkan seringkali ditambahkan supaya produk makanan jadi menjadi lebih tahan lama ketika disimpan namun dapat menimbulkan efek berbahaya bagi masyarakat yang mengkonsumsi. Makanan yang sering ditambahkan formalin sebagai pengawet adalah bahan makanan basah seperti ikan, mie, tahu dan lainnya (Suryadi, 2010; Syarfaini, 2014). Rhodamin B sebagai pewarna merah seringkali ditambahkan supaya makanan terlihat lebih berwarna terang. Makanan yang sering ditambahkan pewarna merah adalah krupuk, sirup, pasta saos, dan lainnya (Rembet, 2017; Putri, 2017).

Praktek analisa formalin dan rhodamin B pada sampel yang dibeli di pasar 
tradisional daerah Jakarta Timur dan Bekasi. Proses uji dilakukan dengan cara peserta dibagi menjadi 6 kelompok, 3 kelompok pertama menganalisa formalin dalam tahu putih, tahu kuning, tahu goreng, mie basah putih dan kuning, sedangkan 3 kelompok lainnya mengerjakan analisa rhodamin B pada krupuk mentah dan yang sudah digoreng berwarna merah dan oranye. Kedua jenis kelompok bergantian mengerjakan analisa formalin dan rhodamin. Peserta dipandu oleh dosen melakukan deteksi cepat seperti warna, bau, tekstur dan bau serta mengerjakan analisa menggunakan kit.

Ciri utama dari makanan yang mengandung formalin adalah tidak mudah busuk atau tengik serta bau bahan asli dari makanan tersebut lebih melemah karena tertutup bau formalin. Sedangkan untuk rhodamin, pada krupuk terlihat warna merah pada krupuk sangat terang baik sebelum maupun sesudah dimasak atau digoreng.

Praktek analisa formalin dan rhodamin B pada sampel yang dibeli di pasar tradisional dilakukan dengan cara peserta dibagi menjadi 6 kelompok, 3 kelompok pertama menganalisa formalin dalam tahu putih, tahu kuning, tahu goreng, mie basah putih dan kuning, sedangkan 3 kelompok lainnya mengerjakan analisa rhodamin B pada krupuk mentah dan yang sudah digoreng berwarna merah dan oranye. Kedua jenis kelompok bergantian mengerjakan analisa formalin dan rhodamin. Peserta dipandu oleh dosen melakukan deteksi cepat seperti warna, bau, tekstur dan bau serta mengerjakan analisa menggunakan kit.

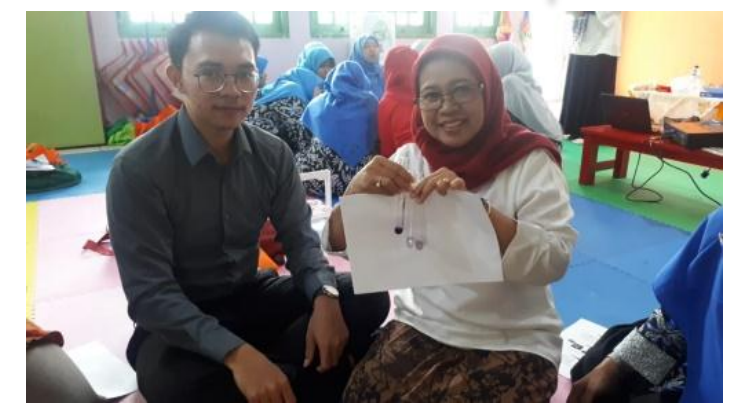

Gambar 5. Contoh hasil positif uji formalin dalam sampel tahu

Hasil yang didapatkan dari uji yang sudah dilakukan antara lain untuk tahu kuning dan tahu goreng positif mengandung formalin. Sampel tahu kuning dan tahu goreng dibeli pada penjual di pasar yang merendam tahu dalam air. Penambahan formalin mungkin dilakukan supaya tahu yang tidak segera laku menjadi tidak cepat busuk. Pada sampel mie menunjukkan sampel mie kuning memberikan hasil positif formalin, mie putih memberikan hasil negatif. Sampel mie kuning yang dibeli memang menunjukkan ciri organoleptis yang sangat jelas dan kuat. Mie kuning berbau menyengat dan tidak didekati lalat ataupun serangga lainnya serta awet selama24 jam tanpa dimasukkan ke dalam lemari pendingin.

Sampel positif rhodamin B ditunjukkan pada sampel krupuk mentah kriting merah dan krupuk matang merah. Untuk krupuk mentah kriting dari warna sudah sangat terlihat merah yangs sangat kuat. Untuk sampel krupuk merah matang warnanya sebenarnya sudah agak pudar namun terlihat bintik-bintik merah pewarna yang kurang rata pada permukaan krupuk. Hal ini sedikit menguatkan dugaan awal ketika deteksi bahwa krupuk mengandung pewarna rhodamin. Deteksi lebih akurat terlihat setelah diuji dengan test-kit.Beberapa peserta memiliki pengetahuan yang baik mengenai bahan tambahan pangan yang aman digunakan dan sebagian lagi masih ada 
yang belum memahami tentang bahan tambahan pangan yang diijinkan maupun yang dilarang.

Evaluasi dilakukan dengan cara memberi pertanyaan kepada peserta dan melakukan diskusi. Peserta menyatakan sangat antusias mengenai materi penggunaan obat serta penggunaan bahan tambahan pangan yang aman. Sesi praktek juga sangat membantu mereka lebih memahami materi yang disampaikan.

\section{PENUTUP}

\section{Simpulan}

Dari hasil pengabdian dapat disimpulkan bahwa peserta yang mengikuti pelatihan mendapatkan tambahan wawasan dan ketrampilan tentang bahan tambahan pangan yang aman maupun berbahaya serta cara deteksi formalin dan rhodamin B dalam makanan di TK Bintara Jaya Bekasi.

\section{Saran}

Perlu edukasi secara berkelanjutan kepada masyarakat baik produsen maupun konsumen agar peduli terhadap bahan berbahaya yang mungkin digunakan dalam makanan, sehingga makanan yang dikonsumsi dan beredar di masyarakat dikategorikan aman.

\section{Ucapan Terima Kasih}

Terimakasih kepada LPPM (Lembaga Penelitian Pengabdian Masyarakat) sebagai pemberi dana kegiatan Pelatihan Deteksi Formalin dan Rhodamin B dalam Makanan bagi Guru dan Wali Murid TK Bintara Jaya Bekasi.

\section{E. DAFTAR PUSTAKA}

International Agency For Research On Cancer. 2006. IARC Monographs on the Evaluation of Carcinogenic Risks to Humans : Formaldehyde. Perancis.

Menteri Dalam Negeri RI dan Kepala Badan POM RI. 2013. PerKaBPOM No 43/2/BPOM/2013, Peraturan tentang Pengawasan Bahan Berbahaya yang Disalahgunakan Dalam Pangan. Jakarta.

Peraturan Menteri Kesehatan Republik Indonesia. 1999. PERMENKES RI No. 1168/MENKES/PER/X/1999 Tentang Bahan Tambahan Makanan. Jakarta.

Peraturan Menteri Kesehatan Republik Indonesia. 2012. PERMENKES RI No. 033/MENKES/PER/2012 tentang Peraturan tentang Bahan Tambahan Pangan. Jakarta.

Peraturan Kepala Badan Pengawas Obat dan Makanan. 2013. No. 36 Tahun 2013 Tentang Batas Maksimum Penggunaan Bahan Tambahan Pangan Pengawet

Peraturan Kepala Badan Pengawas Obat dan Makanan. 2013. No. 37 Tahun 2013 Tentang Batas Maksimum Penggunaan Bahan Tambahan Pangan Pewarna

Putri, A.P., Dhafir, F., dan Laenggeng, A.H. 2017. Analisis Kandungan Rhodamin B Pada Jajanan Makanan Yang Dijual Di Area Pasar Bambaru Kota Palu Dan Pemanfaatannya Sebagai Media Pembelajaran Biologi. e-JIP BIOL Vol.5 (2): 9-19.

Rembet, L.k., Abidjulu, J., dan Kojong, N.S. 2017. Analisis Kadar Rhodamin B Pada Bumbu Jajanan Tahu Yang Beredar di Kota Manado. 


\section{JPM (Jurnal Pemberdayaan Masyarakat) \\ ISSN : 25411977 E- ISSN : 25411977 \\ Vol.5 No.1. 2020 \\ doi https://doi.org/10.21067/jpm.v5i1.3328}

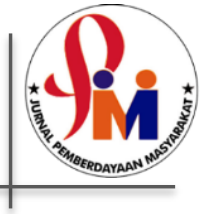

PHARMACON Jurnal Ilmiah Farmasi - UNSRAT, 6(4) : 82-86

Safitri, Y.A., Indrawan, I.W.A., dan Winarsih, S. 2015. Rhodamine B induces oxidative stress and cervical epithelial cell proliferation in the uterus. Toxicology Reports, 2: 14341436.

Syarfaini, Rusmin, M. 2014. Analisis Kandungan Formalin Pada Tahu di Pasar Tradisional Kota Makassar. AlSihah : Public Health Science Journal, 1(2): 1-11.

Suryadi,H., Kurniadi, M., dan Melanie, Y. 2010. Analisis Formalin Dalam Sampel Ikan Dan Udang Segar Dari Pasar Muara Angke. Majalah Ilmu Kefarmasian, 7(3): 16-31 